\section{Transplantation Osteoporosis}

\begin{abstract}
In the past two decades, there has been a rapid increase in the number of organ transplanted worldwide, including Brazil, along with an improvement in survival and quality of life of the transplant recipients. Osteoporosis and a high incidence of fragility fractures have emerged as a complication of organ transplantation. Many factors contribute to the pathogenesis of osteoporosis following organ transplantation. In addition, most patients have some form of bone disease prior to transplantation, which is usually related to adverse effects of end-stage organ failure on the skeleton. This chapter reviews the mechanisms of bone loss that occur both in the early and late post-transplant periods, as well as the features specific to bone loss after kidney, lung, liver, cardiac and bone marrow transplantation. Prevention and treatment for osteoporosis should be instituted prior and in the early and late phase after transplantation, and will also be addressed in this article. (Arq Bras Endocrinol Metab 2006;50/4:783-792)
\end{abstract}

Keywords: Osteoporosis; Transplantation; Immunosuppressive agents; Fractures

\section{RESUMO}

\section{Osteoporose Pós Transplante.}

Nas últimas décadas houve um grande aumento no número de transplantes realizados no Brasil e no mundo, o que proporcionou uma meIhora na sobrevida e qualidade de vida dos pacientes transplantados. A osteoporose e o aumento da prevalência de fraturas por fragilidade óssea têm se mostrado como uma complicação do transplante. Muitos fatores contribuem para a patogênese da osteoporose relacionada ao transplante. Além disso, a maioria dos pacientes apresenta doença óssea antes do transplante, a qual é secundária à doença grave de base. Este artigo revisa os mecanismos da perda óssea que ocorre tanto na fase precoce quanto na fase tardia após o transplante, como também os fatores específicos envolvidos na perda óssea relacionados ao transplante renal, pulmonar, cardíaco, hepático e de medula óssea. A prevenção e o tratamento da osteoporose em todas as fases do transplante também são abordados neste artigo. (Arq Bras Endocrinol Metab 2006;50/4:783-792)

Descritores: Osteoporose; Transplante; Agentes imunossupressores; Fraturas

W ITHIN THE PAST TWO DeCADES, organ transplantation has become established as an important treatment option for several disease states, including end-stage renal disease, chronic liver failure, end-stage pulmonary disease and heart failure. The number of organs transplanted yearly in Brazil has increased during this period; in 2005, more than review article

\author{
Carolina A.M. Kulak \\ Victoria Z.C. Borba \\ Jaime Kulak Júnior \\ Elizabeth Shane
}

Department of Endocrinology and Metabology (CAMK \& VZCB), Federal University of ParanáSEMPR, Department de Obstetrician and Gynecology (JKJ), Federal University of Paraná Curitiba, PR, Brazil; and Department of Medicine (ES), College of Physicians and Surgeons, Columbia University, New York, NY USA.

Received in 05/30/06 Accepted in 06/10/06 
15,000 organ transplants were performed, representing an $18 \%$ increase since 2002 (1). Concomitant with the increasing number of organs transplanted, the survival of the transplant recipients has also improved. Nowadays, many patients live more than 10 years after transplantation. With the increase in life span, bone disease has emerged as a common complication of the transplantation process. Unfortunately, many transplant recipients demonstrate a distinctive propensity for low trauma fractures, which has a negative impact upon their quality of life (2-6). Risk factors for osteoporosis are common among patients who are candidates for transplantation, including older age, dietary calcium deficiency, vitamin D deficiency, physical inactivity, excessive use of tobacco and alcohol. Moreover, medications such as loop diurectics, anticoagulants and glucocorticoids are frequently present in the therapeutic arsenal of these patients. Bone and mineral homeostasis are also influenced by the diseased organ before transplantation, particularly in the case of renal or hepatic failure. However, it is generally considered that post-transplantation immunosuppression plays the pivotal role in the evolution of bone loss and incidence of fractures in organ transplantation recipients (7). Immunosuppressive therapy is required for all transplant recipients in order to prevent rejection of the transplanted organ. Triple immunosuppressive therapy is most commonly used, including glucocorticoids, cyclosporine A (CsA), or tacrolimus (FK506), and azathioprine or mycophenolate mofetil. Glucocorticoids, which have well-known deleterious effects on the skeleton (8-13), are commonly prescribed in high doses (up to $60 \mathrm{mg}$ of prednisone or its equivalent daily) following the transplantation and during episodes of severe rejection. In addition, CsA and FK506 frequently cause nephrotoxicity (14-16), often leading to secondary hyperparathyroidism and increased bone turnover.

In this chapter, we will review the general mechanisms of bone loss after the organ transplantation, as well as the specific features relevant to each organ such as kidney, lung, heart, bone marrow and liver. In addition, we also will address the therapeutic measures recommended before, as well during the early and late periods after transplantation.

\section{MECHANISMS OF POST-TRANSPLANT BONE LOSS}

The natural history of post-transplantation osteoporosis suggests that there are two main phases, I Early and II Late, and that the factors affecting the skeleton dif- fer between the two phases (figure 1). In the early phase (figure 1A), which generally encompasses the first 6 months after transplantation, steroids doses are generally high. This causes marked suppression of osteoblast-mediated bone formation and the inhibition of osteoblast synthetic function, an effect clearly supported by the literature on transplantation osteoporosis that consistently reports decreased serum markers of bone formation, especially osteocalcin. Also during this phase, there is an increase in bone resorption, probably multifactorial in etiology and secondary to the suppressive effect of glucocorticoids on the hypothalamic-pituitary-gonadal axis and on calcium transport across intestinal, renal tubular and parathyroid cell membranes, leading to a rise in serum parathyroid hormone (PTH). In addition, glucocorticoids also decrease synthesis of osteoprotegerin by osteoblasts, thus permitting an increase in binding of RANK-L and to the RANK receptor on precursor and mature osteoclasts, and stimulating osteoclastogenesis. In addition to the deleterious effects of the glucocorticoids, the administration of tacrolimus and cyclosporine also plays a role in the mechanism of bone loss. Both drugs have nephrotoxic effect and the associated decline in renal function leads to decreased synthesis of $1,25(\mathrm{OH})_{2} \mathrm{D}$ and secondary increases in parathyroid hormone secretion, which in turn increases osteoclast-mediated bone resorption. The concomitant administration of high doses of glucocorticoids and cyclosporine (or FK506) is associated with uncoupling of resorption and formation, rapid bone loss and high rates of fracture.

Later during the post-transplant period, when the glucocorticoid doses are tapered to below $5 \mathrm{mg}$ per day, there is recovery of osteoblast function and consequently, an increase in bone formation and recoupling of bone remodeling activity. However, both the direct and the indirect effects of cyclosporine and FK506 continue to influence the skeleton, resulting in secondary hyperparathyroidism and increased bone resorption. During this later phase, rates of bone loss slow and there may even be some recovery, particularly at sites comprised predominantly of cancellous bone (17).

\section{KIDNEY TRANSPLANTATION}

End-stage renal disease (ESRD) is associated with a form of bone disease that is generically referred to as "renal osteodystrophy" (18-20). Many mechanisms are involved in its pathophysiology including calcitriol deficiency, hypocalcemia, hyperphosphatemia, sec- 
A

\section{Mechanisms of Post-Transplant Bone Loss I}

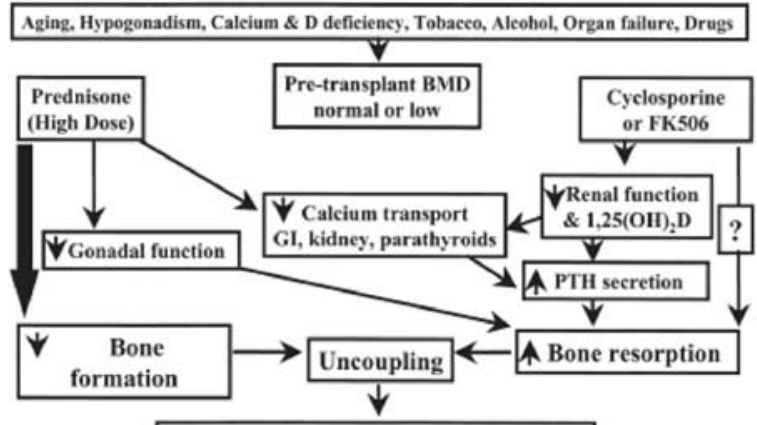

Rapid cancellous bone loss \& fractures

\section{Mechanisms of Post-Transplant Bone Loss II}

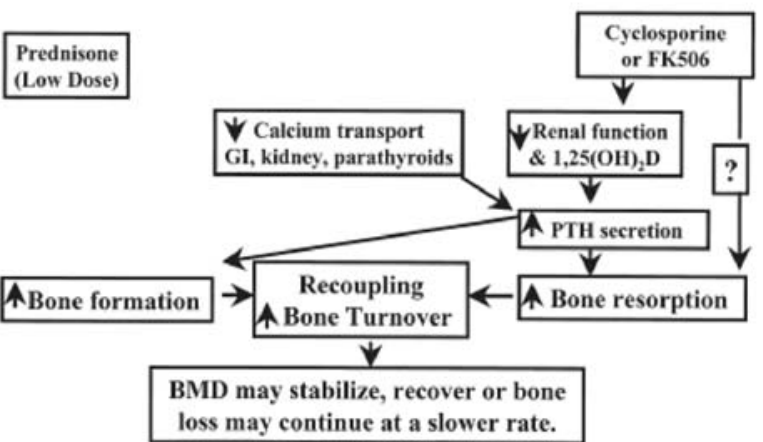

Figure 1. (A) Mechanisms of bone loss in the early post-transplantation period. (B) Mechanisms of bone loss in the later post-transplantation period, after glucocorticoid doses are tapered. With permission from Kulak CAM \& Shane E. Transplantation osteoporosis: Biochemical correlates of pathogenesis and treatment. In: Seibel MJ, Robins SP, Bilezikian JP (eds.) Dynamics of bone and cartilage metabolism, 2nd edition. San Diego: Academic Press, 2006. pp. 515-26)

ondary hyperparathyroidism, metabolic acidosis, and aluminum overload. It is important to note that the measurement of bone mineral density (BMD) and the World Health Organization criteria cannot be used to diagnose osteoporosis in patients with ESRD. This is because any of the several possible histological forms of renal bone disease - hyperparathyroidism, osteomalacia, adynamic bone disease, mixed renal osteodystrophy, aluminum bone disease - may all be associated with low, normal or even elevated BMD. Kidney transplantation is the treatment of choice for ESRD and the demand for this procedure has grown in part because it is associated with higher long-term survival rates and improved quality of life when compared to patients on dialysis. Restoration of renal function after kidney transplantation rectifies many of the disturbances that lead to renal osteodystrophy. There is a resolution of hyperphosphatemia, an increase in serum $1,25(\mathrm{OH})_{2} \mathrm{D}$ levels and a rapid decline in the high levels of PTH, although they may never completely normalize. In the first few months after kidney transplantation, PTH-dependent hypercalcemia and hypophosphatemia may develop. In addition, post-transplant hypophosphatemia may also be related to a primary defect in renal phosphate handling, due to increased serum concentrations of circulating factors (phosphatonins) (19).

Prospective studies indicate that lumbar spine and hip bone loss during the first 3 to 18 months after renal transplantation vary from $4 \%$ to $9 \%$ and $5 \%$ to $9 \%$, respectively (21-23). Although low estradiol and testosterone levels have been associated with accelerated bone loss (24), bone loss has not been consistently related to gender, patient age, cumulative GC dose, rejection episodes, activity level, or PTH levels. Some longitudinal studies document ongoing, though less rapid bone loss, several years after kidney transplantation, while others do not. Despite the improvements in BMD after the first post-transplant year noted in some reports, most studies demonstrate that BMD remains low up to 20 years after transplantation.

Fracture prevalence varies from 7 to $11 \%$ in nondiabetic renal transplant recipients, but is considerably higher in patient transplanted because of diabetic nephropathy and in those who receive kidney-pancreas transplants (25-29). Fractures occur relatively late in the post-transplant period, usually more than three years after transplantation, involving commonly the long bones or metatarsals than the vertebral bodies or ribs (30). A large study realized with 101,039 patients with ESRD demonstrated that kidney transplantation was associated with a $34 \%$ greater risk of hip fracture than continued dialysis (31). A Brazilian study evaluated a prevalence of low bone mineral density, fractures and the associated risk factors in 191 kidney transplantation patients for 3 years (32). This study demonstrated a high prevalence of a $24 \%$ of either a vertebral or appendicular fracture among the kidney recipients.

A number of studies have been conducted to evaluate the efficacy of bisphosphonates or other drugs in the prevention of bone loss after renal transplantation (33-36). Although the antireabsorptive agents may help improve BMD and reduce fractures, there is a widespread concern that bisphosphonates may increase the risk of adynamic bone disease in ESRD patients, and they are not approved for the treatment of these patients (2). Despite these concerns, however, we recommend their use after renal transplantation, at least during the first year when rates of bone loss are 
most rapid. Nowacka-Cieciura et al. evaluated 66 patients who presented osteopenia or osteoporosis before renal transplantation and treated them with alendronate or risedronate, starting 1 month after transplantation and followed by 12 months. The treated patients had an increase of spine and femur neck BMD while the group that did not receive bisphosphonates had a significant BMD reduction (33). Another prospective randomized study investigated different treatment drugs for the prevention of postransplant bone loss. All patients received $500 \mathrm{mg}$ of calcium carbonate and were randomized in four groups: group I received daily alfacalcidol 0.5 microg PO; group II received oral alendronate $5 \mathrm{mg} /$ day; group III intranasal salmon calcitonin 200 UI every other day and group IV was considered a control group. After 12 month, lumbar spine, femur neck and forearm BMD increased in groups I, II, and III, while BMD decreased significantly at all sites in control group. Regarding the other parameters of bone metabolism, intact PTH levels decreased significantly in those patients who received alfacalcidol, improving their secondary hyperparathyroidism, while its reduction in the other groups was insignificant (34). Besides the early bone loss after transplantation, there is also an evidence for significant ongoing bone loss following the first year of the transplant, a slower bone loss of $2 \%$ in long term kidney transplant recipients $(35,36)$, indicating the need of a treatment also in this late period after transplantation.

In summary, patients who undergo renal transplantation sustain early, rapid bone loss and have an increased incidence of fragility fractures. While use of bisphosphonates is controversial in kidney transplant recipients, we regard them as useful to prevent bone loss during the first post-transplant year.

\section{LUNG TRANSPLANTATION}

Patients who are candidates for lung transplantation are highly likely to have osteoporosis even before surgery for several reasons such as hypoxemia, malnutrition, vitamin D deficiency, smoking; decreased immobility and low body weight $(37,38)$. In addition, most of the patients who undergo lung transplantation have experienced prior glucocorticoid therapy (6). A retrospective study in patients with diffuse parenchymal lung disease (DPLD) referred for lung transplantation, revealed that approximately $70 \%$ had low bone density prior the transplantation, and $13 \%$ met WHO criteria for osteoporosis at at least one site (38). In this specific cohort, lower BMD was associated with lower body mass index, whereas there was no association with other clinical factors. Another study conducted with 70 patients awaiting lung transplantation demonstrated that just $34 \%$ had normal spine BMD and $22 \%$ had normal hip BMD, while the prevalence of vertebral fractures was $29 \%$ in patients with chronic obstructive pulmonary disease and $25 \%$ in patients with cystic fibrosis (37). In addition, serum levels of 25-hydroxyvitamin $\mathrm{D}$ were at low end of the normal range, whereas $20 \%$ presented levels compatible to a vitamin $\mathrm{D}$ deficiency, a situation that may have contributed to their bone fragility. Cystic fibrosis, a common disease for which patients undergo lung transplantation, is associated with a rate of vertebral compression and rib fractures 100 and 10 times, respectively, more often than expected (39-42).

Prospective studies have also demonstrated changes in bone mass and fractures incidence in patients who have received a lung transplant (43-47). Spira et al. evaluated BMD in 28 patients prior and 6 to 12 months post lung transplantation. All patients received calcium ( $1 \mathrm{~g}$ per day) and vitamin D (400 UI per day) after the transplantation. There was a $5 \%$ reduction in BMD of both lumbar spine and femur neck, which was associated with cumulative steroid dose after transplantation. In addition, 18\% sustained osteoporotic fractures, despite vitamin D and calcium supplementation. Another prospective study (45) evaluated BMD and fracture incidence in a group of 30 lung-transplant recipients who received antiresorptive therapy shortly after transplantation. Despite therapy, $37 \%$ of the patients sustained a total of 54 atraumatic fractures and 50\% sustained significant bone loss during the first post-transplant year. Pre-transplantation lumbar spine BMD was significantly lower in those who sustained fractures. Fracture patients had longer prior glucocorticoid therapy. In summary, fragility fracture seems to be an important problem in the first year following lung transplantation even in patients who receive therapy for preventing bone loss. Low bone mass and history of glucocorticoids therapy before the lung transplantation increase the risk.

\section{CARDIAC TRANSPLANTATION}

Bone loss and osteoporosis are recognized complications of heart transplantation, occurring most often in the first 6 to 12 months after the transplant (48).

Vertebral fractures occur in about $10 \%$ to $30 \%$ of patients by 3 years. By the time of cardiac trans- 
plantation, $10 \%$ of the patients already have osteoporosis, probably related chronic illness, poor nutrition, limited mobility, weight loss, gonadal dysfunction and medications detrimental to the skeleton. Besides that, renal insufficiency, secondary hyperparathyroidism and abnormal vitamin $\mathrm{D}$ metabolism may contribute to bone loss $(2,17,48,49)$.

The hallmarks of osteoporosis after cardiac transplantation are the high rate of bone loss during the first year ( 2 to $20 \%$ ) along with a high rate of fractures, which occur at higher bone mineral density (BMD) that would be expected in healthy subjects $(48,50)$. Cross sectional and longitudinal studies reported a prevalence of vertebral fractures ranging from 18 to $50 \%$, with lower pre-transplant BMD and female gender as risk factors. After cardiac transplantation lumbar spine BMD falls by $3-10 \%$ during the first 6 months after transplantation and hip BMD fell $5-15 \%$ below pre-transplant levels in 1 year. The rate of bone loss slows after the first year and spine BMD may increase after the third year $(2,17,51)$. Bone remodeling markers are increased after cardiac transplantation and are correlated to intact PTH $(49,52)$. Serum osteoprotegerin, an antiresorptive cytokine, declines during immunosuppressive therapy and accounted for $67 \%$ of the variance of lumbar spine bone density changes during the first 6 months posttransplantation (53).

Bisphosphonates can prevent or at least decrease the rate of bone loss and fractures after cardiac transplantation and should be used with replacement doses of calcium and vitamin D $(54,55)$. Calcitriol at a dose of $0,5 \mu \mathrm{g} /$ day reduced bone loss, however the effect on fracture prevention was not significant (56).

\section{BONE MARROW TRANSPLANTATION}

Bone marrow transplant (BMT) recipients have many known risk factors for developing decreased bone mineral density (BMD) after transplantation (57-59). The pathogenesis of bone disease following BMT differs from other forms of post-transplantation osteoporosis; recipients are usually younger and the time from the diagnosis to the BMT does not exceed 2 years; a history of prolonged bed rest is uncommon. Total body radiation without gonadal shield, a routine procedure in the past, causes hypogonadism and growth hormone deficiency. Immunosuppressive drugs are used in relatively low doses and for short periods of time. Glucocorticoid use is restricted to the treatment of graft-versus-host disease (GVHD) (60,61).

Patients studied after chemotherapy and before BMT show a normal BMD in $72 \%$ (17). The prevalence of bone loss increases after the first year following BMT to rates of $2-9 \%$ at the lumbar spine and $6-11 \%$ at the femoral neck (62). In a study of long-term follow-up of bone loss after BMT, Schulte et al. observed that lumbar spine BMD begins to recover after 12 months of BMT, returning to baseline levels at 48 months. The extent of recovery at the femoral neck is less (61). High levels of bone marrow interleukin-6 during the immediate post-BMT period were related to the bone loss (63). The presence of chronic graft-versus-host disease (GVHD) was another factor associated with a higher risk of osteoporosis in BMT recipients (64-66). Kreutz et al. observed a marked decline in the serum levels of 1,25-dihydroxyvitamin D3 and 25hydroxyvitamin D3 in the course of allogeneic BMT. Whether the suppression of 1,25-dihydroxyvitamin D3 and 25-hydroxyvitamin D3 is just another epiphenomenon of GVHD pathophysiology, or contributes to the immediate post-BMT bone loss is not clear (66).

\section{LIVER TRANSPLANTATION AND OSTEOPOROSIS}

Liver transplantation is a well-established procedure with 5 -year survival rates of over $70 \%$ in most centers (67). Osteoporosis and fractures are common findings in patients with chronic liver disease (68) and increase the risk for fracture after surgery. Bone loss is a common complication after liver transplantation. Estimates of the prevalence or incidence of fragility fracture following transplantation have varied widely. This may vary due to a number of factors including differences in patient selection, immunosuppressive regimens and the diagnostic criteria used for vertebral fracture. A wide range of vertebral fracture rates $(3-44 \%)$ has been reported among cirrhotic patients and the disparities among the studies are probably due to differences in the populations examined (69). Reduced bone formation in chronic liver disease has been ascribed to several factors. Additional contributory factors include vitamin D deficiency, glucocorticoid use, reduced physical activity, low body weight and reduced muscle mass (68). The natural history of bone loss after liver transplantation is characterized by a marked decrease in lumbar spine BMD by $3.5-24 \%$, primarily during the first 3-6 months, with gradual improvement thereafter. Fracture incidence is also highest in the first year (69). The vertebrae and ribs are the most common fracture sites. The balance of the biochemical data 
reported suggests that the state of low bone turnover observed in many patients with liver failure converts to a high turnover state that persists indefinitely after liver transplantation. The biochemical change from low to high bone turnover has been confirmed by quantitative histomorphometry (71). Type of liver disease, glucocorticoid exposure, and markers of bone turnover do not reliably predict fracture risk.

\section{PREVENTION AND MANAGEMENT OF TRANSPLANTATION OSTEOPOROSIS}

\section{Pre-transplantation measures}

All transplant candidates should be evaluated and treated before transplantation, as bone disease is common in patients awaiting organ transplantation. Patients must be encouraged to modify lifestyle factors with adverse effects on the skeleton, such as immobilization, smoking and alcohol abuse. Other factors that can be corrected include hypogonadism, vitamin $\mathrm{D}$ deficiency and secondary hyperparathyroidism. In addition, the use of glucocorticoids should be minimized to the extent possible. An evaluation of BMD and some parameters of bone and mineral metabolism should be performed prior to the organ transplantation. This previous evaluation could be helpful to select patients who would benefit from an immediate therapy. For patients with endstage renal disease, an evaluation and treatment for renal osteodystrophy according to accepted guidelines is highly recommended (71).

All patients should receive the recommended daily allowance for calcium $(1,000-1,500 \mathrm{mg} / \mathrm{d})$ and vitamin D (400-800IU/d).

\section{Prevention of early and late post-transplantation bone loss}

The lack of reliable clinical predictors to identify individual patients who will experience osteoporotic fractures renders all transplant recipients candidates for preventive therapy. It is well known that the rates of bone loss and fracture incidence are highest immediately following transplantation. Therefore, preventive and therapeutic measures should be instituted at that time and without delay.

Measures such as exercise, calcium and vitamin $\mathrm{D}$, calcitriol and antireapsortives agents have been considered for prevention of early post-transplantation bone loss.

Exercise. The importance of physical activity in restoring BMD was demonstrated in three prospective, randomized, albeit very small, studies conducted in heart $(72,73)$ and lung (74) transplant recipients. The type of training consisted of supervised exercises of the lumbar extensor muscles ( 1 day/week) and upper and lower body (2 days/week), started 2 months following transplantation and continued for 6 months.

Calcium and vitamin D. Although the replacement of calcium and vitamin D fails to prevent clinically significant bone loss after the transplantation, as demonstrated by virtually all studies $(44,47)$, repletion of calcium and vitamin D remains very important in these patients. In our opinion, all transplant recipients should receive $1,000 \mathrm{mg}$ elemental calcium and at least 400 IU of vitamin D daily.

Active vitamin $D$ metabolites. Calcium and calcidiol (25-OHD) were effective in maintaining bone mass in heart transplantation patients (75) and renal transplant recipients (76). The efficacy of calcitriol in preventing bone loss in the early period after transplantation was well demonstrated at doses $\geq 0.5 \mu \mathrm{g}$ daily $(55,56)$. In addition, its use in the late period after transplantation has also been demonstrated to prevent bone loss in renal transplant recipients (77). However, in other studies, active vitamin D metabolites are of limited effectiveness. In addition, hypercalcemia and hypercalciuria, common side effects of vitamin D metabolites, may develop at any point during treatment. Frequent monitoring of urine and serum is required. In our opinion, active vitamin D metabolites should not be selected as first-line treatment because of their limited effectiveness and narrow therapeutic window.

Calcitonin. Although ineffective in preventing early bone loss, calcitonin may have some benefit in the later post-transplant period in liver (78) and renal (79) transplant recipient and can be considered if other agents are contraindicated or poorly tolerated.

Gonadal hormone replacement. Few studies have approached the replacement of sex steroids for transplant recipients. Isoniemi et al. (80), in an uncontrolled study of postmenopausal liver transplantation recipients, demonstrated that the use of transdermal estradiol was effective in increasing BMD of lumbar spine and femur neck over a period of two years.

Bisphosphonates. These potent antiresorptive agents are an obvious option in preventing the rapid bone loss, that occurs mainly in the early phase after transplantation and that is associated with increased bone resorption. Studies using intravenous pamidronate $(0.5 \mathrm{mg} / \mathrm{kg})$, given at the time of renal transplantation and 1 month later, prevented bone loss at the apparent 4 years after transplantation (82). Similar results have been reported in a controlled randomized 
study of 34 patients with cystic fibrosis (83), and in non-randomized studies of heart (84), lung (47), and liver transplant recipients (85).

The use of pamidronate was also effective in the prevention of the ongoing bone loss when initiated 2 years after transplantation in 13 cardiac and 21 liver transplant recipients (86). Another intravenous bisphosphonate, zoledronic acid, has been used in a randomized double-blind, placebo-controlled trial of 62 patients after liver transplantation. It was administrated in a dose of $4 \mathrm{mg} 7$ days before and 1, 3, 6 and 9 months after the transplantation. At the end of 12 months, it was demonstrated that zoledronic acid had effectively prevented bone loss (87). Several studies conducted in transplant recipients demonstrated that the use of oral alendronate ( $10 \mathrm{mg}$ daily) was effective in reducing bone loss at the femoral neck and lumbar spine in both early and late periods after transplantation $(58,88-90)$. In summary, oral or intravenous bisphosphonates, in conjunction with calcium and vitamin $\mathrm{D}$, are effective in preventing post-transplantation bone loss when started shortly after grafting. The optimal dose, timing, and frequency, particularly of intravenous bisphosphonate administration, remain to be determined.

\section{CONCLUSIONS}

Patients with end-stage organ failure and candidates for all types of transplantation have significant risk factors for osteoporosis and abnormal mineral metabolism before the organ transplantation. The exposure to high doses of glucocorticoids and calcineurin inhibitors such as cyclosporine $\mathrm{A}$ and tacrolimus, is associated with rapid bone loss and high fracture incidence immediately after transplantation. Effective therapies should incorporate pre-transplant measures to treat preexisting bone diseases and also aggressive prevention of bone loss during the first six to 12 months transplantation. The optimal dose, timing and frequency of administration of these therapies remain to be determined. At present, most controlled trials lack sufficient statistical power to demonstrate efficacy for fracture prevention. More studies are required to determine the best agent and route of administration to prevent this common complication of organ transplantation.

\section{REFERENCES}

1. Sistema Nacional de Transplantes. Available at: <http://dtr2001.saude.gov.br/transplantes>.
2. Cohen A, Shane E. Osteoporosis after solid organ and bone marrow transplantation. Osteoporos Int 2003; 14:617-30.

3. Cohen A, Ebeling P, Sprague S, Shane E. Transplantation osteoporosis. In: Favus MJ (ed). Primer on the metabolic bone diseases and disorders of mineral metabolism. Washington: American Society for Bone and Mineral Research, 2003. pp. 370-9.

4. Shane E, Rivas MC, Silverberg SJ, Kim TS, Staron RB, Bilezikian JP. Osteoporosis after cardiac transplantation. Am J Med 1993;94:257-64.

5. Compston JE. Osteoporosis after liver transplantation. Liver Transplant 2003:9:321-30.

6. Aris RM, Neuringer IP, Weiner MA, Egan TM, Ontjes D. Severe osteoporosis before and after lung transplantation. Chest 1996; 109(5): 1176-83.

7. Matsuda S, Koyasu S. Mechanism of action of cyclosporine. Immunopharmacology 2000;47:1 10-25.

8. Boling EP. Secondary osteoporosis: underlying disease and the risk for glucocorticoid-induced osteoporosis. Clin Ther 2004;26:1-14.

9. Van Staa TP, Leufkens HG, Abenhaim L, Zhang B, Cooper C. Use of oral corticosteroids and risk of fractures. J Bone Miner Res 2000; 15:993-1000

10. Lafage-Proust MH, Boudignon B, Thomas T. Glucocorticoid-induced osteoporosis: pathophysiological data and recent treatments. Joint Bone Spine 2003;70:10918.

11. Hofbauer LC, Gori F, Riggs BL, Lacey DL, Dunstan CR, Spelsberg TC, et al. Stimulation of osteoprotegerin ligand and inhibition of osteoprotegerin production by glucocorticoids in human osteoblastic lineage cells: potential paracrine mechanisms of glucocorticoidinduced osteoporosis. Endocrinology 1999; 140:4382-9.

12. Weinstein RS, Jilka RL, Parfitt AM, Manolagas SC. Inhibition of osteoblastogenesis and promotion of apoptosis of osteoblasts and osteocytes by glucocorticoids. J Clin Invest 1998; 102:274-82.

13. O’Brien CA, Jia D, Plotkin LI, Bellido T, Powers CC, Stewart SA, et al. Glucocorticoids act directly on osteoblasts and osteocytes to induce their apoptosis and reduce bone formation and strength. Endocrinology 2004; 145:1835-41.

14. Epstein S. Post-transplantation bone disease: the role of immunosuppressive agents on the skeleton. J Bone Miner Res 1996;11:1-7.

15. Kirino S, Fukunaga J, Ikegami S, Tsuboi H, Kimata M, Nakata $\mathrm{N}$, et al. Regulation of bone metabolism in immunosuppressant (FK 506) treated rats. J Bone Miner Metab 2004:22:554-60

16. Bennett WM, DeMattos A, Meyer MM, Andoh T, Barry JM. Chronic cyclosporine nephropathy: the Achilles heel of immunosuppressive therapy. Kidney Int 1996;50:1089100.

17. Kulak CAM, Shane E. Transplantation osteoporosis: biochemical correlates of pathogenesis and treatment. In: Seibel MJ, Robbins SP, Bilezikian JP (eds). Dynamics of bone and cartilage metabolism, 2nd edition. San Diego: Academic Press, 2006. pp. 515-26. 
18. Goodman WG, Coburn JW, Slatopolsky E, Salusky IB, Quarles LD. Renal osteodystrophy in adults and children. In: Favus M (ed). Primer on the metabolic bone diseases and disorders of mineral metabolism. Washington: American Society for Bone and Mineral Research, 2003. pp. 430-47.

19. Green J, Debby H, Lederer E, Levi M, Zajicek HK, Bick T. Evidence for a PTH-independent humoral mechanism in post-transplant hypophosphatemia and phosphaturia. Kidney Int 2001;60:1182-96.

20. Hruska KA, Teitelbaum SL. Renal osteodystrophy. N Engl J Med 1994;333:166-75

21. Almond MK, Kwan JTC, Evans K, Cunningham J. Loss of regional bone mineral density in the first 12 months following renal transplantation. Nephron 1994;66:52-7.

22. Julian BA, Laskow DA, Dubovsky J, Dubovsky EV, Curtis JJ, Quarrles LD. Rapid loss of vertebral bone density after renal transplantation. N Engl J Med 1991;325:544-50.

23. Kwan JTC, Almond MK, Evans K, Cunningham J. Changes in total body bone mineral content and regional bone mineraldensity in renal patients following renal transplantation. Miner Electrolyte Metab 1992; 18:166-8.

24. Nisbeth U, Lindh E, Ljunghall S, Backman U, Fellstrom B. Fracture frequency after kidney transplantation. Transplant Proc 1994:26:1764.

25. Brandenburg VM, Ketteler M, Heussen N, Politt D, Frank $\mathrm{RD}$, Westenfeld $\mathrm{R}$, et al. Lumbar bone mineral density in very long-term renal transplant recipients: impact of circulating sex hormones. Osteoporos Int 2005;16(12):161120.

26. Nowacka-Cieciura E, Cieciura T, Baczkowska T, Kozinska-Przybyl O, Tronina O, Chudzinski W, et al. Bisphosphonates are effective prophylactic of early bone loss after renal transplantation. Transplant Proc 2006;38(1):165-7.

27. El-Agroudy AE, El-Husseini AA, El-Sayed M, Mohsen T, Ghoneim MA. A prospective randomized study for prevention of postrenal transplantation bone loss. Kidney Int 2005;67(5):2039-45.

28. Pichette V, Bonnardeaux A, Prudhomme L, Gagne M, Cardinal $\mathrm{J}$, Ouimet D. Long-term bone loss in kidney transplant recipients: A cross-sectional and longitudinal study. Am J Kidney Dis 1996;28:105-14.

29. Cruz DN, Wysolmerski JJ, Brickel HM, Gundberg CG, Simpson CA, Mitnick MA, et al. Parameters of high boneturnover predict bone loss in renal transplant patients: a longitudinal study. Transplantation 2001;72:83-8.

30. Grotz WH, Mundinger A, Gugel B, Exner V, Kirste G, Schollmeyer PJ. Bone fracture and osteodensitometry with dual energy $\mathrm{x}$-ray absorptiometry in kidney transplant recipients. Transplantation 1994;58:912-5.

31. Nisbeth $U$, Lindh $E$, Ljunghall $S$, Backman U, Fellstrom B. Fracture frequency after kidney transplantation. Transplant Proc 2004;26:1764.

32. Nisbeth $U$, Lindh E, Ljunghall S, Backman U, Fellstrom B. Increased fracture rate in diabetes mellitus and females after renal transplantation. Transplantation 1999; $67: 1218-22$
33. Smets YF, Van der Pijl JW, Fijter JW, Ringers J, Lemkes HH, Hamdy NA. Low bone mass and high incidence of fractures after successful simultaneous pancreas-kidney transplantation. Nephrol Dial Transplant 1998; 13:1250-5.

34. Chiu MY, Sprague SM, Bruce DS, Woodle ES, Thistlethwaite JR, Josephson MA. Analysis of fracture prevalence in kidney-pancreas allograft recipients. J Am Soc Nephrol 1998:9:677-83.

35. Ball AM, Gillen DL, Sherrard D, Weiss NS, Emerson SS, Seliger $\mathrm{SL}$, et al. Risk of hip fracture among dialysis and renal transplant recipients. JAMA 2002;288:3014-8.

36. Ramsey-Goldman R, Dunn JE, Dunlop DD, Stuart FP, Abecassis MM, Kaufman DB, et al. Increased risk of fracture in patients receiving solid organ transplants. J Bone Miner Res 1999; 14:456-63.

37. Braga Junior JW, Neves RM, Pinheiro MM, Frisoli Junior A, Castro $\mathrm{CH}$, Szejnfeld VL, et al. Prevalence of low trauma fractures in long-term kidney transplant patients with preserved renal function. Braz J Med Biol Res 2006;39(1):137-47.

38. Shane E, Silverberg SJ, Donovan D, Papadopoulos A, Sharon RB, Addesso V, et al. Osteoporosis in lung transplantation candidates with end-stage pulmonary disease. Am J Med 1996; 101:262-9.

39. Caplan-Shaw CE, Arcasoy SM, Shane E, Lederer DJ, Wilt JS, O'Shea MK, et al. Osteoporosis in diffuse parenchymal lung disease. Chest 2006; 129(1):140-6.

40. Aris RM, Renner JB, Winders AD, Buell HE, Riggs DB, Lester $G E$, et al. Increased rate of fractures and severe kyphosis: sequelae of living into adulthood with cystic fibrosis. Ann Intern Med 1998;128(3): 186-93.

41. Bachrach LK, Loutit CW, Moss RB. Osteopenia in adults with cystic fibrosis (see comments). Am J Med 1994;96:27-34.

42. Donovan DS Jr, Papadopoulos A, Staron RB, Addesso V, Schulman L, McGregor C, et al. Bone mass and vitamin $D$ deficiency in adults with advanced cystic fibrosis lung disease. Am J Respir Crit Care Med 1998;157:1892-9.

43. Conway SP, Oldroyd B, Morton A, Truscott JG, Peckham DG. Effect of oral bisphosphonates on bone mineral density and body composition in adult patients with cystic fibrosis: a pilot study. Thorax 2004;59:699-703.

44. Aringer $\mathrm{M}$, Kiener $\mathrm{H}$, Koeller $\mathrm{M}$, Artemiou $\mathrm{O}$, Zuckerman $A$, Wieselthaler $G$, et al. High turnover bone disease following lung transplantation. Bone 2002;23:485-8.

45. Ferrari SL, Nicod LP, Hamacher J, Spiliopoulos A, Slosman $\mathrm{DO}$, Rochat T, et al. Osteoporosis in patients undergoing lung transplantation. Eur Respir J 1996:9:2378-82.

46. Shane E, Papadopoulos A, Staron RB, Addesso V, Donovan $D, M c G r e g o r ~ C$, et al. Bone loss and fracture after lung transplantation. Transplantation 1999;68:220-7.

47. Spira A, Gutierrez C, Chaparro C, Hutcheon MA, Chan CK. Osteoporosis and lung transplantation: a prospective study. Chest 2000;117:476-81.

48. Trombetti A, Gerbase MW, Spiliopoulos A, Slosman DO, Nicod LP, Rizzoli R. Bone mineral density in lung transplant recipients before and after graft: prevention of lumbar spine post-transplantation-accelerated bone loss by pamidronate. J Heart Lung Transplant 2000; 19:736-43. 
49. Lindsay R. Bone loss after cardiac transplantation. N Engl J Med 2004;350:7514

50. Guo C-Y, Johnson A, Locke TJ, Eastell R. Mechanism of bone loss after cardiac transplantation. Bone 1998; 22:267-71.

51. Hofle G, Saely CH, Tautermann G, Aczel S, Holzmuller H, Drexel $H$. Relationship between various measures of bone mineral density and vertebral fractures in cardiac transplant recipients. Swiss Med Wkly 2004;134:215-20.

52. Hoffman FM. Outcomes and complications after heart transplantation: a review. J Cardiovasc Nurs 2005;20(5 suppl):S31-42

53. Cohen A, Addonizio LJ, Lamour JM, Addesso V, Staron RB, Gao P, et al. Osteoporosis in adult survivors of adolescent cardiac transplantation may be related to hyperparathyroidism, mild renal insufficiency, and increased bone turnover. J Heart Lung Transplant 2005;24:696-702.

54. Fahrleitner A, Prenner G, Leb G, Tscheliessnigg KH Piswanger-Solkner C, Obermayer-Pietsch B, et al. Serum osteoprotegerin is a major determinant of bone density development and prevalent vertebral fracture status following cardiac transplantation. Bone 2003;32:96-106.

55. Dodidou P, Bruckner T, Hosch S, Haass M, Klar E, Sauer P, et al. Better late than never? Experience with intravenous pamidronate treatment in patients with low bone mass or fractures following cardiac or liver transplantation. Osteoporos Int 2003; 14:82-9.

56. Shane E, Addesso V, Namerow PB, McMahon DJ, Lo SH, Staron RB, et al. Alendronate versus calcitriol for the prevention of bone loss after cardiac transplantation. $\mathrm{N}$ Engl J Med 2004;350:767-76

57. Sambrook $P$, Henderson NK, Keogh A, MacDonald $P$, Glanville A, Spratt P, et al. Effect of calcitriol on bone loss after cardiac or lung transplantation. J Bone Miner Res 2000:15:1818-24.

58. Schimmer AD, Mah K, Bordeleau L, Cheung A, Ali V, Falconer $\mathrm{M}$, et al. Decreased bone mineral density is common after autologous blood or marrow transplantation. Bone Marrow Transplant 2001;28:387-91.

59. Kashyap A, Kandeel F, Yamauchi D, Palmer JM, Niland JC, Molina A, et al. Effects of allogeneic bone marrow transplantation on recipient bone mineral density: A prospective study. Blood Marrow Transplant 2000;6(3A):344-51.

60. Castaneda S, Carmona L, Carvajal I, Arranz R, Diaz A, Garcia-Vadillo A. Reduction of bone mass in women after bone marrow transplantation. Calcif Tissue Int 1997:60:343-7.

61. Ebeling PR, Thomas DM, Erbas B, Hopper JL, Szer J, Grigg AP. Mechanisms of bone loss following allogeneic and autologous hemopoietic stem cell transplantation. J Bone Miner Res 1999; 14:342-50.

62. Schulte CM, Beelen DW. Bone loss following hematopoietic stem cell transplantation: a long-term follow-up. Blood 2004; 103:3635-43.

63. Schulte C, Beelen D, Schaefer UW, Mann K. Variations in 1a,25-dihydroxyvitamin D3 and 25-hydroxyvitamin D3 serum levels during allogeneic bone marrow transplantation. Osteoporos Int 2000;1 1:344-53.

64. Lee WY, Kang MI, On ES, Oh KW, Han JH, Cha BY, et al. The role of cytokines in the changes in bone turnover following bone marrow transplantation. Osteoporos Int 2002; 13:62-8.
65. Baker KS, Gurney JG, Ness KK, Bhatia R, Forman SJ, Francisco $\mathrm{L}$, et al. Late effects in survivors of chronic myeloid leukemia treated with hematopoietic cell transplantation: results from the Bone Marrow Transplant Survivor Study. Blood 2004; 104: 1898-906.

66. Kerschan-Schindl K, Mitterbauer M, Fureder W, Kudlacek S, Grampp S, Bieglmayer C, et al. Bone metabolism in patients more than five years after bone marrow transplantation. Bone Marrow Transplant 2004;34:491-6.

67. Kreutz M, Eissner G, Hahn RA, Drobnik, Holler E. Variations in 1 alpha,25-dihydroxyvitamin D3 and 25-hydroxyvitamin D3 serum levels during allogeneic bone marrow transplantation. Bone Marrow Transplant 2004;33:871-3.

68. Neuberger J. Liver transplantation. Quart J Med 1999:92:547-50.

69. American Gastroenterological Association Medical position statement: osteoporosis in hepatic disorders. Gastroenterology 2003; 125:937-40.

70. Leidig-Bruckner G, Hosch S, Dodidou P, Ritchel D, Conradt $C$, Klose $C$, et al. Frequency and predictors of osteoporotic fractures after cardiac or liver transplantation: a follow-up study. Lancet. 2001;357:342-7.

71. Monegal A, Navasa M, Guanabens N, Peris P, Pons F, Osaba MJ, et al. Osteoporosis and bone mineral metabolism in cirrhotic patients referred for liver transplantation. Calcif Tissue Int 1997;60:148-54.

72. Elder $G$. Pathophysiology and recent advances in the management of renal osteodystrophy. J Bone Miner Res 2002:17:2094-164.

73. Braith RW, Mills J, Welsch MA, Keller JW, Pollack ML. Resistance exercise training restores bone mineral density in heart transplant recipients. J Am Coll Cardiol 1996:28: 1471-7.

74. Braith RW, Magyari PM, Fulton MN, Aranda J, Walker T, Hill JA. Resistance exercise training and alendronate reverse glucocorticoid-induced osteoporosis in heart transplant recipients. J Heart Lung Transplant 2003;22:1082-90.

75. Mitchell MJ, Baz MA, Fulton MN, Lisor CF, Braith RW. Resistance training prevents vertebral osteoporosis in lung transplant recipients. Transplantation 2003;76:557-62.

76. Meys E, Terreaux-Duvert F, Beaume-Six T, Dureau G, Meunier PJ. Effects of calcium, calcidiol, and monofluorophosphate on lumbar bone mass and parathyroid function in patients after cardiac transplantation. Osteoporos Int 1993;3:329-32.

77. Talalaj M, Gradowska L, Marcinowska-Suchowierska E, Durlik M, Gaciong Z, Lao M. Efficiency of preventive treatment of glucocorticoid-induced osteoporosis with 25-hydroxyvitamin D3 and calcium in kidney transplant patients. Transplant Proc 1996;28:3485-7.

78. Ugur A, Guvener N, Isiklar I, Karakayali H, Erdal R. Efficiency of preventive treatment for osteoporosis after renal transplantation. Transpl Proc 2000;32:556-7.

79. Valero MA, Loinaz C, Larrodera L, Leon M, Moreno E, Hawkins F. Calcitonin and bisphosphonates treatment in bone loss after liver transplantation. Calcif Tissue Int 1995; $57: 15-9$

80. Grotz WH, Rump LC, Niessen A, Schmidt-Gayk $H$, Reichelt A, Kirste $G$, et al. Treatment of osteopenia and osteoporosis after kidney transplantation. Transplantation 1998:66:1004-8. 
81. Isoniemi H, Appelberg J, Nilsson CG, Makela P, Risteli J, Hockerstedt K. Transdermal oestrogen therapy protects postmenopausal liver transplant women from osteoporosis. A two-year follow-up study. J Hepatol 2001; 34:299-305

82. Fan $S$, Almond MK, Ball E, Evans $K$, Cunningham J. Pamidronate therapy as prevention of bone loss following renal transplantation. Kidney Int 2000;57:684-90.

83. Fan SL, Kumar S, Cunningham J. Intravenous pamidronate as treatment for osteoporosis after kidney transplantation: a prospective study. Kidney Int 2003;63:2275-9.

84. Aris RM, Lester GE, Renner JB, Winders A, Blackwood AD, Lark RK, et al. Efficacy of pamidronate for osteoporosis in cystic fibrosis patients following lung transplantation. Am J Respir Crit Care Med 2000; 162:941.

85. Krieg M, Seydoux C, Sandini L, Goy JJ, Berguer DG, Thiebaud D, et al. Intravenous pamidronate as a treatment for osteoporosis after heart transplantation: a prospective study. Osteoporos Int 2001;12:112-6.

86. Reeves H, Francis R, Manas D, Hudson M, Day C. Intravenous bisphosphonate prevents symptomatic osteoporotic vertebral collapse in patients after liver transplantation. Liver Transpl Surg 1998:4:404-9.

87. Dodidou P, Bruckner T, Hosch S, Haass M, Klar E, Sauer P, et al. Better late than never? Experience with intravenous pamidronate treatment in patient with low bone mass or fractures following cardiac or liver transplantation. Osteoporos Int 2003; 14:82-8.
88. Crawford BA, Kam C, Pavlovic J, Byth K, Handelsman DJ, Angus PW, et al. Zolendronic acid prevents bone loss after liver transplantation: a randomized, double blind, placebo-controlled trial. Ann Intern Med 2006;144 (4): 137.

89. Giannini S, Dangel A, Carraro G, Nobile M, Rigotti P, Bonfante $\mathrm{L}$, et al. Alendronate prevents further bone loss in renal transplant recipients. J Bone Miner Res 2001;16:2111-7.

90. Jeffrey JR, Leslie WD, Karpinski MF, Nickerson PW, Rush DN. Prevalence and treatment of decreased bone density in renal transplant recipients: a randomized prospective trial of calcitriol versus alendronate. Transplantation 2003:76:1498-502

91. Koc M, Tuglular S, Arikan H, Ozener C, Akoglu E. Alendronate increases bone mineral density in long-term renal transplant recipients. Transplant Proc 2002; $34: 2111-3$.

\section{Address for correspondence:}

Carolina A. Moreira Kulak Rua Agostinho Leão Júnior 285 80030-013 Curitiba, PR, Brasil. 